\title{
Article \\ Effects of Thinning Practice, High Pruning and Slash Management on Crop Tree and Stand Growth in Young Even-Aged Stands of Planted Silver Birch (Betula pendula Roth)
}

\author{
Jens Peter Skovsgaard 1,*(i), Ulf Johansson ${ }^{2}$, Emma Holmström ${ }^{1}$ (), Rebecka McCarthy Tune ${ }^{1,3}$, \\ Clémentine Ols ${ }^{1,4}\left(\mathbb{D}\right.$ and Giulia Attocchi ${ }^{1}$ \\ 1 Southern Swedish Forest Research Centre, Swedish University of Agricultural Sciences, \\ S-230 53 Alnarp, Sweden; emma.holmstrom@slu.se (E.H.); rebecka.mccarthy@gmail.com (R.M.T.); \\ clementine.ols88@ign.fr (C.O.); giulia.attocchi@slu.se (G.A.) \\ 2 Tönnersjöheden Experimental Forest, Swedish University of Agricultural Sciences, \\ S-313 25 Simlångsdalen, Sweden; ulf.johansson@slu.se \\ 3 NEPCon Sweden AB, c/o Stanza, S-652 21 Karlstad, Sweden \\ 4 Laboratoire d'Inventaire Forestier, Institut National de l'Information Géographique et Forestière, \\ F-54000 Nancy, France \\ * Correspondence: jps@slu.se
}

\section{check for}

updates

Citation: Skovsgaard, J.P.; Johansson, U.; Holmström, E.; Tune, R.M.; Ols, C.; Attocchi, G. Effects of Thinning Practice, High Pruning and Slash Management on Crop Tree and Stand Growth in Young Even-Aged Stands of Planted Silver Birch (Betula pendula Roth). Forests 2021, 12, 225. https:// doi.org/10.3390/f12020225

Academic Editors: Nelson Thiffault and Brad Pinno

Received: 2 December 2020

Accepted: 30 January 2021

Published: 16 February 2021

Publisher's Note: MDPI stays neutral with regard to jurisdictional claims in published maps and institutional affiliations.

Copyright: (c) 2021 by the authors. Licensee MDPI, Basel, Switzerland. This article is an open access article distributed under the terms and conditions of the Creative Commons Attribution (CC BY) license (https:// creativecommons.org/licenses/by/ $4.0 /)$.
Abstract: The objective was to quantify the influence of thinning, high pruning and slash management on crop tree and stand growth in young even-aged stands of planted silver birch (Betula pendula Roth). This study was based on two field experiments, aged six and eleven years at initiation and re-measured after six and eight years, respectively. Treatments included the unthinned control, moderate thinning mainly from below (removing $28-33 \%$ of standing volume), point thinning to favor 300 trees per ha and with no thinning elsewhere in the plot (removing 16-25\%), and heavy thinning leaving 600 evenly distributed potential future crop trees per ha (removing 64-75\%). Slash management (extraction or retention) was applied to heavily thinned plots. High pruning removing $30-70 \%$ of the green crown was carried out in some plots with point or heavy thinning on 300 or 600 trees per ha, respectively. Stand volume growth increased with increasing pre-treatment mean annual volume increment and decreased with increasing thinning intensity as compared to the unthinned control. LS-means estimates indicated a reduction for moderate thinning by $14 \%$, for point thinning by $12 \%$ and for heavy thinning (combined with pruning) by $62 \%$. However, in the youngest experiment, heavy thinning (without pruning) reduced growth by $54 \%$. Combining these results with results from a similar experiment in Canada, the reduction in stand volume growth $\left(\operatorname{Red}_{I v \%}\right)$ depending on thinning removal $\left(\operatorname{Rem}_{V \%}\right)$, both expressed as a percentage of the unthinned control, was quantified as $\operatorname{Red} I v \%=-23.67+1.16 \cdot \operatorname{Re} m_{V \%}$ (calibration range: $30-83 \%$ ). For heavy thinning (large quantities of slash), slash extraction resulted in no reduction in stand volume growth as compared to slash retention. The instantaneous numeric reduction in the average stem diameter of the 300 thickest trees per ha $\left(D_{300}\right)$ due to thinning was $3.5,15-21 \%$ and $955-11 \%$ with moderate, point and heavy thinning, respectively. The subsequent average annual increase in $D_{300}$ during the observation period was $8.5 \%, 25$ and $18 \%$, respectively. In the youngest experiment, pruning in unthinned plots led to a reduction in the annual increase of $D_{300}$ by $14 \%$, and heavy thinning in unpruned plots led to an increase by $30 \%$. The growth of pre-selected potential future crop trees increased with increasing thinning intensity. In heavily thinned plots, pruning reduced growth increasingly with increasing pruning severity; LS-means estimates indicated $21 \%$ larger growth on stem diameter for unpruned trees and 3\% for pruned trees. As an adverse side effect, heavily thinned plots with only 600 trees per ha were at increased risk of windthrow for some years after the thinning intervention. In the oldest experiment, $95-21 \%$ of the trees in these plots were damaged by wind.

Keywords: thinning; pruning; slash; windthrow; wind stability; potential future crop trees; tree growth; stand growth; birch; Sweden 


\section{Introduction}

Broadleaved forest types are gradually becoming increasingly important in Sweden. This is a consequence of improving growth conditions, adaptation of the forest to climate change, and increasing awareness of the economic potential and environmental value of broadleaved forests. With an above-ground, standing wood volume of $453 \times 10^{6} \mathrm{~m}^{3}$, or $13 \%$ of the total wood volume in the country, birch is by far the largest broadleaved forest resource [1]. Among birch species, silver birch (Betula pendula Roth) accounts for $329 \times 10^{6} \mathrm{~m}^{3}$, or $73 \%$ of the birch volume. This species consequently represents a substantial commercial potential for timber production.

For a given site and genetic origin, the commercial potential depends largely on thinning and pruning practices in the individual stand. A number of experiments and studies quantify the influence of thinning on tree and stand growth in even-aged stands of silver birch [2-7] (see also [8] and the summary overview [9]). As for pruning, most studies focus on wood quality issues (e.g., [10,11]), some on work efficiency (e.g., [12]), and very few on growth response (e.g., [13]). The studies of growth response to thinning or pruning generally refer to dense stands with complete or almost complete canopy closure, late interventions, moderate stem number reductions and moderate pruning.

Recently, some silviculturists have advocated early heavy thinning combined with early high pruning of pre-selected, potential future crop trees as a means to faster produce high-quality timber [14]. Early heavy thinning accelerates crown expansion and, in turn, diameter growth at a time when the individual tree is most responsive to increasing space and availability of growth resources. Early high pruning eliminates the disadvantage of excessive branch growth due to thinning and it furthermore improves stem quality in terms of knottiness earlier and faster than would happen through natural pruning in the absence of thinning. In summary, this early intensive silviculture works to reduce rotation length and, thereby, production risks. Birch is well suited for early intensive silviculture because it is light demanding, diameter growth peaks early, wood quality is largely independent of growth rate, branches die early and shed slowly, and the incidence of false red heart discoloration increases with increasing age [12,15-20].

During 2010-2012, we established two combined thinning and pruning experiments in young, even-aged stands of silver birch to provide a foundation for analyzing the influence of early thinning and early high pruning on crop tree and stand growth. Moreover, in some plots, slash extraction was included as an experimental factor. This paper reports some results following six to eight years of observation. The presentation is based on four analyses:

1. The effects of thinning practice on stand volume growth.

2. The effects of slash extraction/retention on stand volume growth.

3. The effects of crop tree selection, thinning and pruning on the size of crop trees and other large trees.

4. The effects of thinning intensity and pruning severity on the growth of crop trees.

\section{Materials and Methods}

The study was based on two thinning experiments in even-aged stands of silver birch, established by the Swedish University of Agricultural Sciences: experiment no. 1278 located at Duveke (lat. $55^{\circ} 57^{\prime}$, long. $13^{\circ} 02^{\prime}$ ) near the city of Helsingborg [21], and no. 1289 located at Vallerstad (lat. $57^{\circ} 09^{\prime}$, long. $13^{\circ} 58^{\prime}$ ) near the city of Värnamo [22].

Both stands were planted with genetically improved stock of silver birch from the breeding program of Skogforsk (the Forest Research Institute of Sweden) at Ekebo [23]. Both stands were initially fenced. The areas were formerly stocked with stands of even-aged Norway spruce (Picea abies (L.) Karst.).

Experiment 1278 (elevation $\approx 70 \mathrm{~m}$ ) is located on soils developed from organic postglacial deposits and, in some parts, glacial till, in both cases overlying a bedrock of Triassic Keuper sandstone or Silurian shale. The area is flat and poorly drained. 
Experiment 1289 (elevation $\approx 200 \mathrm{~m}$ ) is located on glacial till overlying a bedrock of granite. The terrain is quite heterogeneous with moist patches, rocks and outcrops of bedrock.

Experiment 1278 was planted in 2001 using one-year-old seedlings originating from the greenhouse seed orchard Ekebo 3. The experiment was installed and measured during autumn 2010-spring 2011. Some plots had ingrowth of naturally seeded birch and other tree species. All plots were re-measured during spring 2019.

Experiment 1289 was planted in 2007 using one-year-old seedlings originating from the greenhouse seed orchard Ekebo 4. The experimental plots used for this analysis were installed and measured during spring 2012. All plots had ingrowth of naturally seeded birch and other tree species. All plots were re-measured during spring 2018.

Both experiments include a wide range of thinning practices. Some trees in some plots were subjected to different degrees of early high pruning (cf. 'Pruning treatments' below and [12]). Moreover, in some plots, one plot half was subjected to slash extraction. Due to the above-mentioned differences in initial site and stand characteristics and in experimental set-up, the two experiments were analyzed separately.

\subsection{Thinning Treatments}

The thinning treatments include four main regimes (Figure 1). Each thinning treatment was specified in terms of residual stem density (RSD) at different stages of stand development, expected final stem density at the end of the rotation (FSD), and target stem diameter at $1.30 \mathrm{~m}$ above ground level (target $\mathrm{DBH}$ ):

UC: Unthinned control. No pre-commercial thinning, no commercial thinning, no pruning or other management interventions at any time throughout the rotation. $\mathrm{FSD} \approx 750-900 \mathrm{ha}^{-1}$. Target $\mathrm{DBH} \approx 18 \mathrm{~cm}$.

T1500: Moderate thinning mainly from below and at regular intervals according to standard guidelines (cf. [9]). We label this treatment T1500 because RSD $\approx 1500 \mathrm{ha}^{-1}$ at top height $12-13 \mathrm{~m}$ is a key point in the guide curve. FSD $\approx 275-300 \mathrm{ha}^{-1}$. Target $\mathrm{DBH} \approx 30 \mathrm{~cm}$.

PT300: Thinning for 300 evenly distributed potential future crop trees per ha ("point thinning"; cf. [24]). Heavy point thinning at regular intervals to favor only these trees. FSD $\approx 275-300 \mathrm{ha}^{-1}$. Target $\mathrm{DBH} \approx 30 \mathrm{~cm}$.

T600: Very heavy thinning leaving 600 evenly distributed potential future crop trees per ha at first thinning. Subsequent selective thinning at crown contact of individual trees, resulting in a gradually decreasing stem density. $\mathrm{FSD} \approx 100 \mathrm{ha}^{-1}$. Target $\mathrm{DBH} \approx 50 \mathrm{~cm}$.

Experiment 1278 includes three replicates of each thinning treatment and three additional unthinned control plots, located in three randomized blocks (mean plot size $\approx 0.20$ ha, range: $0.10-0.31 \mathrm{ha}$ ). Blocking was based on pre-treatment total above-ground wood volume. All thinning treatments were initiated at installation of the experiment (Table 1).

In terms of standing wood volume, the thinning removals in 1278 were $28-33 \%$ in T1500, $16-25 \%$ in PT300 and $72-75 \%$ in T600. The corresponding residual basal areas were $68-72 \%, 75-85 \%$, and $24-28 \%$, respectively, of the plot-specific pre-treatment basal areas. The three heavily thinned T600 plots were damaged by windthrow during a violent windstorm on 28-29 October 2013, according to the Swedish Meteorological and Hydrological Institute (SMHI) with mean wind speed on nearby locations at up to $31 \mathrm{~m} \cdot \mathrm{s}^{-1}$. This reduced the residual stem number by 9,12 and $21 \%$ in each T600 plot, respectively. Most damaged trees were uprooted. We further examine the windthrow in the final discussion (Section 4.5). 




Figure 1. The four thinning treatments: $\mathrm{UC}=$ unthinned control, $\mathrm{T} 1500=$ moderate thinning mainly from below $\left(\mathrm{N}=1500 \mathrm{ha}^{-1}\right.$ at $\left.\mathrm{H}=12 \mathrm{~m}\right), \mathrm{PT} 300$ = point thinning for 300 pre-selected potential future crop trees per ha, $\mathrm{T} 600=$ very heavy thinning $\left(\mathrm{N}=600 \mathrm{ha}^{-1}\right.$ after first thinning intervention). Legend: small dot $=$ a tree, large $\operatorname{dot}=$ a potential future crop tree.

Table 1. Number of research plots used for analyses of stand volume growth, crop tree growth and slash management effects. Nominal thinning treatment indicates the treatment applied during the observation period (exp. 1278: 2011-2019; exp. 1289: 2012-2018) and may deviate from the treatment scheduled for continuation (for example, some unthinned plots in exp. 1289 were pruned in 2012 and thinned in 2018, cf. Table 2 and the main text).

\begin{tabular}{llcccccc}
\hline \multicolumn{2}{c}{ Treatment } & \multicolumn{3}{c}{ Exp. 1278 } & \multicolumn{3}{c}{ Exp. 1289 } \\
\hline Thinning & Pruning & Stand & Crop Tree & Slash & Stand & Crop Tree & Slash \\
\hline UC & No & 6 & & 9 & 4 & \\
UC & Yes & & & & 4 & \\
T1500 & No & 3 & 3 & & & \\
PT300 & No & 3 & 3 & & 2 & 2 \\
T600 & No & & 3 & 3 & & & \\
T600 & Yes & 3 & 3 & & & \\
\hline
\end{tabular}

Table 2. Number of pruned and unpruned trees available for the analysis of crop tree growth and of pruning effects on individual tree growth. Nominal thinning treatment indicates the treatment applied during the observation period (PT300 or T600) or the treatment scheduled to be initiated later (PT300 unthinned and T600 unthinned).

\begin{tabular}{lcccc}
\hline \multirow{2}{*}{ Treatment } & \multicolumn{2}{c}{ Exp. 1278 } & \multicolumn{2}{c}{ Exp. 1289 } \\
\cline { 2 - 5 } & Pruned & Unpruned & Pruned & Unpruned \\
\hline PT300 & 0 & 158 & - & - \\
PT300 unthinned & - & - & 138 & 547 \\
T600 unthinned & - & - & 257 & 0 \\
T600 & 327 & 83 & 0 & 298 \\
\hline
\end{tabular}


Experiment 1289 includes two blocks, one with five plots and one with seven (mean plot size $\approx 0.21$ ha, range: $0.12-0.30 \mathrm{ha}$ ). Blocking was based on geographic proximity. Due to insufficient natural pruning, thinning was postponed to 2018 in all but two T600 plots. One unthinned plot was excluded from the analysis due to issues with the measurement of tree height in 2012. In terms of thinning treatment, experiment 1289 contributed nine unthinned plots and two plots thinned as T600 (Table 1).

In terms of standing wood volume, the thinning removals in 1289 were $64-69 \%$ in T600. The corresponding residual basal areas were $31-35 \%$ of the pre-treatment basal areas. Here, scattered windfall in the two T600 plots amounted to $1.6 \%$ and $0.5 \%$, respectively, based on stem number.

In both experiments, potential future crop trees in PT300 and T600 plots were selected based on superior growth potential (large stem diameter and large, essentially symmetrical crown), high stem quality (straight and upright stem, no low forking, preferably thin branches), absence of visible 'defects', and good health. In order to ensure an even spatial distribution of crop trees, each plot was subdivided into squares of approximately $10 \mathrm{~m}$ $\times 10 \mathrm{~m}$ aiming for three or six crop trees in each square, depending on thinning regime, and an approximate stem map was drawn continuously during the selection process. We quantify the immediate numeric effects of the selection as part of the analysis of the size and change in size of crop trees and other large trees (' $D_{300}$ selection and treatment effects').

\subsection{Pruning Treatments}

In experiment 1278, high pruning was carried out in the three T600 plots [12]. In these plots, most trees were pruned, but some remained unpruned. In experiment 1289, no pruning was carried out in T600 plots thinned in 2012. Instead, high pruning was done on pre-selected potential future crop trees in two plots scheduled for thinning treatment PT300 and in two plots scheduled for T600 thinning at a later stage of stand development.

Pruning was carried out by removing all living and dead branches from below to a certain height above ground level (bottom-up pruning). Trees in experiment 1278 were pruned in June 2011, February 2012 and May 2012 (two trees per $10 \mathrm{~m} \times 10 \mathrm{~m}$ square on each occasion) using a pole-saw. Trees in experiment 1289 were pruned in July and August 2012 , on some trees using pruning shears (secateurs), on others using a pole-saw.

In experiment 1278, the height of pruned trees ranged from 7.7 to $10.0 \mathrm{~m}$, and on average trees were pruned to $6.11 \mathrm{~m}$ (range 4.20-6.82 m). In experiment 1289, the height of pruned trees ranged from 2.8 to $6.7 \mathrm{~m}$, and on average trees were pruned to $2.71 \mathrm{~m}$ (range: $1.23-4.81 \mathrm{~m})$.

\subsection{Slash Management}

A randomized split-plot design was applied to plots treated with T600 thinning. In one half of each plot the thinning slash was removed (slash extraction), in the other half it remained on the ground (slash retention). The installation of this treatment was motivated by the large quantities of slash following T600 thinning, its possible impact on tree growth, soil processes and biodiversity (ground flora, soil fauna, etc.) and the commercial potential of slash for firewood, woodchips, advanced biomaterials and other products.

Felling was carried out during the leaf-off season. Slash removed comprised wood residues left on the ground after felling, including stems, branches and the majority of twigs. No stumps or roots were removed. A small terrain vehicle was used for extraction.

Due to irregularities in the procedure the exact borderlines in experiment 1289 could not be retraced at re-measurement. So, only three plots in experiment 1278 (mean size of plot halves $\approx 0.13$ ha, range: $0.10-0.16$ ha) were available for the analysis of slash management effects (Table 1). The proportion of trees damaged by wind was evenly distributed across plot halves and ranged between 7.5 and $12.0 \%$, except in the northern half of the northernmost plot where $31.7 \%$ was damaged. 


\subsection{Data Collection}

All trees in the experiments were numbered individually and measured for stem diameter at $1.30 \mathrm{~m}$ above ground level $(d, \mathrm{~cm}$; also referred to as diameter at breast height or dbh), and a sample of trees in each plot was measured for total tree height $(h, \mathrm{~m})$. The height of trees not measured for height was calculated based on the standard model $h=1.30+(d /(\alpha+\beta \cdot d))^{3}$, where $\alpha$ and $\beta$ are plot-specific coefficients $[25,26]$. Total aboveground single-tree volume $\left(v, \mathrm{~m}^{3}\right)$ was calculated based on a regional model for birch (for $d \geq 4.5 \mathrm{~cm}$ : [27], eq. 190-01; for $d<4.5 \mathrm{~cm}$ : [28]).

From these basic variables, stand values were derived for quadratic mean diameter $\left(D_{g}\right)$, mean diameter of the 300 thickest trees per ha $\left(D_{300}\right)$, stand top height $\left(H_{100}\right.$, the average height of the 100 thickest trees per ha), stand basal area $(G)$, stand volume $(V)$ and other variables reflecting stand structure and growth. These were considered as potential explanatory variables in models used for the analyses (final models explained below). As an example, pre-treatment stand volume varied from 52.7 to $75.6 \mathrm{~m}^{3} \mathrm{ha}^{-1}$ in experiment 1278 and from 3.4 to $8.5 \mathrm{~m}^{3} \mathrm{ha}^{-1}$ in experiment 1289 (Table 3). Differences within an experiment in this order of magnitude may certainly affect tree and stand growth and are therefore included in the modelling procedure.

Table 3. Stand values for stem number ( $N$, including ingrowth), stand basal area $(G)$, stand volume $(V)$, quadratic mean diameter $\left(D_{g}\right)$, stand top height $\left(H_{100}\right.$, the average height of the 100 thickest trees per ha), number of pre-selected potential future crop trees $\left(N_{P F C T}\right)$ and arithmetic mean diameter of potential future crop trees $\left(D_{P F C T}\right)$ at initiation of the experiment and at the end of the observation period for experiments 1278 (age: 11-19 years) and 1289 (age: 6-12 years). The table includes unadjusted mean values per treatment type ( $n=$ number of plots). Legend: PT300u and T600u refer to so far unthinned plots.

\begin{tabular}{|c|c|c|c|c|c|c|c|c|c|c|c|c|c|c|c|c|c|}
\hline \multirow{3}{*}{$\operatorname{Exp}$} & \multirow{3}{*}{ Treatment } & \multirow{3}{*}{$n$} & \multicolumn{4}{|c|}{ Before Thinning } & \multicolumn{7}{|c|}{ Remaining Stand/After Thinning } & \multicolumn{4}{|c|}{ Thinning Removal } \\
\hline & & & Age & $N$ & G & V & $N$ & $N_{P F C T}$ & G & $V$ & $D_{g}$ & $D_{P F C T}$ & $H_{100}$ & $N$ & G & V & $D_{g}$ \\
\hline & & & years & ha $^{-1}$ & $\mathrm{~m}^{2} \mathrm{ha}-1$ & $\mathrm{~m}^{3} \mathrm{ha}^{-1}$ & ha-1 & $h^{-1}$ & $\mathrm{~m}^{2} \mathbf{h} \mathbf{a}^{-1}$ & $\mathrm{~m}^{3} \mathrm{ha}^{-1}$ & $\mathrm{~cm}$ & $\mathrm{~cm}$ & m & ha $^{-1}$ & $\mathrm{~m}^{2} \mathrm{ha}^{-1}$ & $\mathrm{~m}^{3} \mathrm{ha}^{-1}$ & $\mathrm{~cm}$ \\
\hline \multirow[t]{8}{*}{1278} & UC & 5 & 11 & 3938 & 12.96 & 59.8 & 3869 & & 12.96 & 59.7 & 6.6 & & 9.12 & 0 & 0.00 & 0.0 & 0.0 \\
\hline & & & 19 & 2822 & 25.21 & 161.6 & 2817 & & 25.21 & 161.3 & 10.7 & & 14.51 & & & & \\
\hline & РT300 & 3 & 11 & 3666 & 13.54 & 63.0 & 3040 & 299 & 10.84 & 50.0 & 6.8 & 9.0 & 9.49 & 563 & 2.70 & 12.7 & 7.8 \\
\hline & & & 19 & 2335 & 22.70 & 146.3 & 1288 & 256 & 13.92 & 89.9 & 11.8 & 14.5 & 14.45 & 1041 & 8.78 & 56.3 & 10.4 \\
\hline & $\mathrm{T} 1500$ & 3 & 11 & 5466 & 13.78 & 63.8 & 3853 & & 9.71 & 44.6 & 5.8 & & 9.12 & 1401 & 4.07 & 18.5 & 6.2 \\
\hline & & & 19 & 2615 & 23.48 & 152.6 & 1193 & & 14.61 & 97.4 & 12.5 & & 14.76 & 1386 & 8.87 & 55.1 & 9.1 \\
\hline & T600 & 3 & 11 & 3998 & 14.11 & 66.3 & 602 & 602 & 3.71 & 17.8 & 8.8 & 8.7 & 9.45 & 3351 & 10.40 & 48.2 & 6.6 \\
\hline & & & 19 & 792 & 9.60 & 56.6 & 519 & 519 & 8.90 & 53.0 & 14.8 & 14.6 & 13.55 & 228 & 0.70 & 3.5 & 6.2 \\
\hline \multirow[t]{8}{*}{1289} & $\mathrm{UC}$ & 5 & 6 & 2778 & 1.41 & 5.5 & 2723 & & 1.4 & 5.5 & 2.8 & & 4.36 & 0 & 0.00 & 0.0 & 0.0 \\
\hline & & & 12 & 14270 & 8.10 & 53.4 & 7893 & & 7.9 & 46.6 & 4.1 & & 8.81 & & & & \\
\hline & РT300u & 2 & 6 & 2724 & 1.68 & 5.6 & 2682 & 303 & 1.68 & 5.6 & 2.8 & 3.6 & 5.53 & 0 & 0.00 & 0.0 & 0.0 \\
\hline & & & 12 & 14080 & 10.43 & 59.0 & 6728 & 299 & 8.05 & 39.0 & 3.9 & 8.3 & 10.58 & 622 & 2.39 & 11.9 & 6.9 \\
\hline & $\mathrm{T} 600 \mathrm{u}$ & 2 & 6 & 2603 & 2.37 & 8.0 & 2599 & 609 & 2.37 & 8.0 & 3.4 & 3.9 & 5.83 & 0 & 0.00 & 0.0 & 0.0 \\
\hline & & & 12 & 11867 & 10.52 & 56.0 & 6370 & 565 & 4.01 & 20.1 & 2.9 & 8.4 & 11.06 & 1723 & 6.51 & 33.0 & 6.3 \\
\hline & T600 & 2 & 6 & 2481 & 1.89 & 6.3 & 583 & 583 & 0.62 & 2.1 & 3.7 & 3.6 & 5.38 & 1877 & 1.27 & 4.2 & 2.9 \\
\hline & & & 12 & 20786 & 5.88 & 31.6 & 12328 & 577 & 5.87 & 28.4 & 2.5 & 10.0 & 10.76 & 6 & 0.01 & 0.0 & 4.0 \\
\hline
\end{tabular}

For pruned and some unpruned trees, a number of stem quality variables were also measured. These included height above ground level of the lowest live branch $\left(h_{l l b}, \mathrm{~m}\right)$ pruning height $\left(h_{p}, \mathrm{~m}\right.$; height above ground level of the lowest remaining, live branch after pruning) and forking height (not used in this analysis).

At re-measurement, all potential future crop trees and other trees used for comparison in the analyses of individual tree growth were re-identified accurately and re-measured (Table 2). Due to ingrowth, some other trees in some plots could not be re-identified reliably by their number, but all trees were measured and identified as originally planted or as ingrowth.

\subsection{Stand Volume Growth and Thinning Practice}

For some plots, the analysis of thinning effects included the combined effect of thinning and pruning, which, due to the experimental design, could not be separated (cf. Tables 1 and 2). For T600 plots, whole-plot estimates of stand volume growth were used (i.e., including both 
plot halves) and the effect of slash management was analyzed separately (cf. 'Stand volume growth and slash management').

In both experiments, ingrowth occurring after installation of the treatments was accounted for. In all plots, ingrowth during the observation period was negligible in terms of tree size and, consequently, in terms of competition with the birch originally planted on the area.

Stand volume growth depending on thinning practice was analyzed and hypotheses tested based on analyses of covariance. The variation in site productivity among experimental plots was accounted for by including the pre-treatment mean annual volume increment (MAI) of each individual plot as a covariate (cf. $[29,30])$. When calculating pre-treatment MAI, the denominator was adjusted by subtracting the age of the seedlings at planting.

In mathematical terms, the full model may be specified as

$$
I_{V, j}=\mu+\alpha_{T C}\left(T C_{j}\right)+\beta \cdot M A I_{p r e-t r t, j}+\varepsilon_{j}
$$

where $I_{V}$ denotes mean annual stand volume growth (total above-ground wood volume, including ingrowth) during the observation period, $T C$ is a class variable referring to treatment combination (Table 1), $M A I_{\text {pre-trt }}$ denotes pre-treatment mean annual volume increment at plot level, $\mu$ is the overall mean, $\alpha_{T C}$ and $\beta$ are coefficients, $\varepsilon \sim \mathrm{N}\left(0, \sigma^{2}\right)$ are model residuals, and subscript $j$ refers to plot number.

Due to the extent of windthrow in T600 plots and the essentially solitary nature of trees, initial post-thinning volume estimates for T600 plots were adjusted to include only trees surviving to the re-measurement. Moreover, for comparability across plots, stand volume growth was scaled proportionally to stem density in order to represent 600 trees per ha, i.e., $I_{V, 600}=I_{V, \text { adjusted }} \cdot 600 / N_{\text {end }}$, where $N_{\text {end }}$ is the stem density at re-measurement.

The model was iteratively reduced based on the usual F-test in a backward elimination process until all remaining variables were significant. The test level was set at $p=0.05$. Throughout, the tests were based on the assumption of homogeneous variance and independently, normally distributed errors. Based on the inspection of residual plots, mean and median values and distribution percentiles (not shown), these assumptions were justified.

The statistical analyses of stand volume growth and thinning practice were performed using SAS version 9.4 (SAS Institute, Cary, NC, USA).

\subsection{Stand Volume Growth and Slash Management}

Stand volume growth depending on slash management (retention or extraction) was analyzed based on pairwise comparison of paired plot halves ( $t$-test) in the three heavily thinned T600 plots in experiment 1278. It was a pre-requisite for this analysis that the inherent site productivity of pairwise plot halves were roughly identical. Pre-treatment stand volume (adjusted and scaled to 600 trees per ha as previously explained) differed among plot halves by $0.6,1.4$ and $4.5 \%$, respectively, while post-treatment average tree height differed by $-0.2,-0.3$ and $-2.7 \%$, respectively. Considering the small variation of both variables, we found it justified that data could be analyzed in a pairwise comparison.

The basic variable used in the analysis was

$$
\Delta_{j}=I_{V, j R}-I_{V, j E}
$$

where $I_{V}$ denotes mean annual stand volume growth (no ingrowth included as very little was present in these plots) during the observation period, subscript $j$ refers to plot number, $R$ refers to slash retention, and $E$ refers to slash extraction. For comparability across plot halves, stand volume growth was adjusted and scaled to 600 trees per ha as previously explained.

The null hypothesis $\Delta_{\text {mean }}=0$ (no influence of slash management on stand volume growth), where $\Delta_{\text {mean }}$ denotes the mean value of $\Delta$, was tested based on the usual $t$-test 
under the assumption of normally, independently distributed errors. The test level was set at $p=0.05$.

The statistical analyses of stand volume growth and slash management were performed using SAS version 9.4 (SAS Institute, Cary, NC, USA).

\section{7. $D_{300}$ Selection and Treatment Effects}

In this analysis, we aimed to quantify the combined effects of crop tree selection, thinning and pruning on the size of crop trees and other large trees. Potential future crop trees were identified in treatments PT300 and T600 already at installation of the experiment, while in treatments UC and T1500 no such trees were selected. Moreover, in T1500, the selection criteria for trees to remain or remove were different. In order to establish a baseline for comparison across all treatments, we based the analysis on $D_{300}$. We used the immediate change in $D_{300}$ at initiation of the experiment to quantify the numeric, instantaneous effect of crop tree selection and of thinning, and we refer to this as the selection effect. We used the average annual increase in $D_{300}$ during the observation period as a proxy for the growth of the expected final crop trees.

The selection effect $\left(\Delta_{D 300 i n i t}\right)$ was quantified based on the model

$$
\Delta_{D 300 i n i t, j}=\mu+\alpha_{T}\left(T_{j}\right)+\beta \cdot M A I_{\text {pre-trt }, j}+\varepsilon_{j}
$$

where $\Delta_{D 300 i n i t, j}=D_{300 i n i t B T, j}-D_{300 i n i t A T, j}, D_{300 i n i t}$ is the mean dbh of the 300 thickest trees per ha at initiation of the experiment, subscript $B T$ refers to the before thinning status, $A T$ refers to the after thinning status, and other symbols, specifications and procedures are as explained for Equation (1). The rationale of testing $M A I_{\text {pre-trt }}$ as co-variate was that stand density, as considered in three-dimensional space, might influence the selection, and, since $M A I_{\text {pre-trt }}$ was used in other models, we preferred this over $V_{\text {init }}$. The test level was set at $p=0.05$. $D_{300 \text { initBT }}$ was tested as an additional or alternative co-variate in Model (3), but was rejected (the correlation between $M A I_{\text {pre-trt }}$ and $D_{300 i n i t B T}$ was $r=0.730^{* *}$ for exp. 1278 and $r=0.919^{* * *}$ for exp. 1289).

The average annual increase in the mean dbh of the 300 thickest trees per ha $\left(I_{D 300}\right)$ was analyzed based on the model

$$
I_{D 300, j}=\mu+\alpha_{T}\left(T_{j}\right)+\beta \cdot M A I_{p r e-t r t, j}+\varepsilon_{j}
$$

where $I_{D 300}=D_{300 i n i t}-D_{300 \text { end }}, D_{300 i n i t}$ and $D_{300 \text { end }}$ are the mean dbh of the 300 thickest trees per ha at initiation of the experiment (after thinning) and at the end of the observation period, respectively, and all other variables, specifications and procedures are as explained for Equation (1). For treatments PT300 and T600, $D_{300}$ was calculated based only on the selected crop trees and only those that remained alive until the end of the observation period. For other treatments, $D_{300}$ was calculated based on the 300 thickest trees per ha in the residual stand at any time.

The statistical analyses of $D_{300}$ selection and treatment effects were performed using SAS version 9.4 (SAS Institute, Cary, NC, USA).

\subsection{Crop Tree Growth}

The growth of pre-selected potential future crop trees was analyzed for treatments PT300 and T600 based on dbh. In some plots, additional trees had been measured to a similar standard and were thus available for comparison (Table 2).

We tested three alternative, mixed linear models (5.1,5.2 and 5.3), which were calibrated for different subsets of data. The models can be specified in a common equation as

$$
i_{d, i j}=\mu+\beta_{T}\left(T_{j}\right)+\beta_{P}\left(P_{i j}\right)+\beta_{S}\left(S_{i j}\right)+\theta \cdot M A I_{p r e-t r t, j}+\sum \delta_{k} \cdot x_{i j k}+\alpha_{j}+\varepsilon_{i j}
$$

where $i_{d}$ denotes average annual growth on dbh during the observation period, $T$ is a class variable indicating thinning treatment, $P$ is an indicator variable of pruning or no 
pruning, $S$ is an indicator variable of the presence or absence of slash at the base of the individual tree, $M A I_{\text {pre-trt }}$ denotes pre-treatment mean annual volume increment during the observation period, $x$ is a set of continuous variables reflecting the growth capacity of an individual tree, $\mu$ is the overall mean, $\beta_{T}, \beta_{P}, \beta_{S}, \theta$ and $\delta$ are coefficients, $\alpha \sim \mathrm{N}\left(0, \sigma_{\alpha}^{2}\right)$ is the error attributed to plot, $\varepsilon \sim \mathrm{N}\left(0, \sigma_{\varepsilon}^{2}\right)$ is the residual error, subscript $i$ refers to tree number, $j$ refers to plot number, and $k$ identifies the relevant continuous variable. The specification of $x$-variables varied among models.

Model (5.1) was calibrated with all trees available for analysis. Model (5.1) included $d_{\text {init }}$ (dbh at initiation of the experiment) as the only continuous predictor variable $x$, and the slash variable $S$ was excluded. Model (5.2) was calibrated with pruned trees for which pruning height had been measured. Model (5.2) included $d_{\text {init }}, c_{l}=h-h_{p}$ (reflecting remaining crown length) and all class variables as candidate predictor variables. Model (5.3) was calibrated for pruned trees for which pruning height and the height of the lowest live branch had been measured. Model (5.3) included $d_{\text {init }}, c_{\text {prop }}=\left(h-h_{p}\right) /\left(h-h_{l l b}\right)$ (the proportion of crown remaining after the treatment, reflecting pruning severity) and all class variables as candidate predictor variables.

Prior to the final analyses logarithmic transformation of numeric variables was considered. Moreover, $d_{\text {init }}^{2}$ was tested as a potential predictor in the otherwise untransformed models. In all cases, the untransformed variables were found to perform better.

The goodness-of-fit of each model was evaluated graphically based on residual plots (not shown) and by the coefficient of determination $\left(R^{2}\right)$. As there is no consensus for calculating $R^{2}$ in mixed models, we adopted a method [31] according to which

$$
R_{m}^{2}=\frac{\sigma_{f}^{2}}{\sigma_{f}^{2}+\sigma_{\alpha}^{2}+\sigma_{\varepsilon}^{2}}
$$

and

$$
R_{c}^{2}=\frac{\sigma_{f}^{2}+\sigma_{\alpha}^{2}}{\sigma_{f}^{2}+\sigma_{\alpha}^{2}+\sigma_{\varepsilon}^{2}}
$$

where $R_{m}^{2}$ is the marginal coefficient of determination concerned with variance explained by fixed factors, $R_{c}^{2}$ is the conditional coefficient of determination concerned with variance explained by both fixed and random effects, $\sigma_{f}^{2}$ is the variance calculated from the fixed effects components of the mixed model, and other terms are as explained above.

Due to opposite effects on the individual tree growth of pruning and canopy closure in unthinned plots of experiment 1289 scheduled for PT300 or T600 treatment, and due to unbalanced data in terms of dbh and treatments, Model (5) could not be calibrated with reasonable and consistent parameter estimates. Consequently, the final analysis of crop tree growth included only experiment 1278.

The statistical analyses of crop tree growth were performed using the free software $R$ (The $R$ Foundation).

\section{Results}

\subsection{Stand Volume Growth and Thinning Practice}

In experiment 1278 (15 plots), stand volume growth during the observation period (age 11-19 years) varied between 4.54 and $16.03 \mathrm{~m}^{3} \mathrm{ha}^{-1}$ year $^{-1}$. Two plots deviated from the general pattern and, based on statistical tests, were considered outliers. One of these (T1500) suffered from extremely poor drainage at installation, and the other one (UC) had ingrowth with a large proportion of birch of genetically unimproved origin. These plots were omitted from the final analysis. The final model included no interaction term.

According to the final model, stand volume growth depended on site productivity (as reflected by pre-treatment MAI) as well as on thinning treatment (Figure 2). Growth increased with increasing pre-treatment MAI and was largest in the unthinned control, marginally smaller in the two classical thinning treatments T1500 and PT300 and substan- 
tially smaller in the very heavy thinning T600 (Table 4). LS-means estimates indicated a growth reduction for the T1500 treatment by $13.7 \%$ as compared to the unthinned control, by $12.3 \%$ for PT 300 , and by $62.4 \%$ for T600.
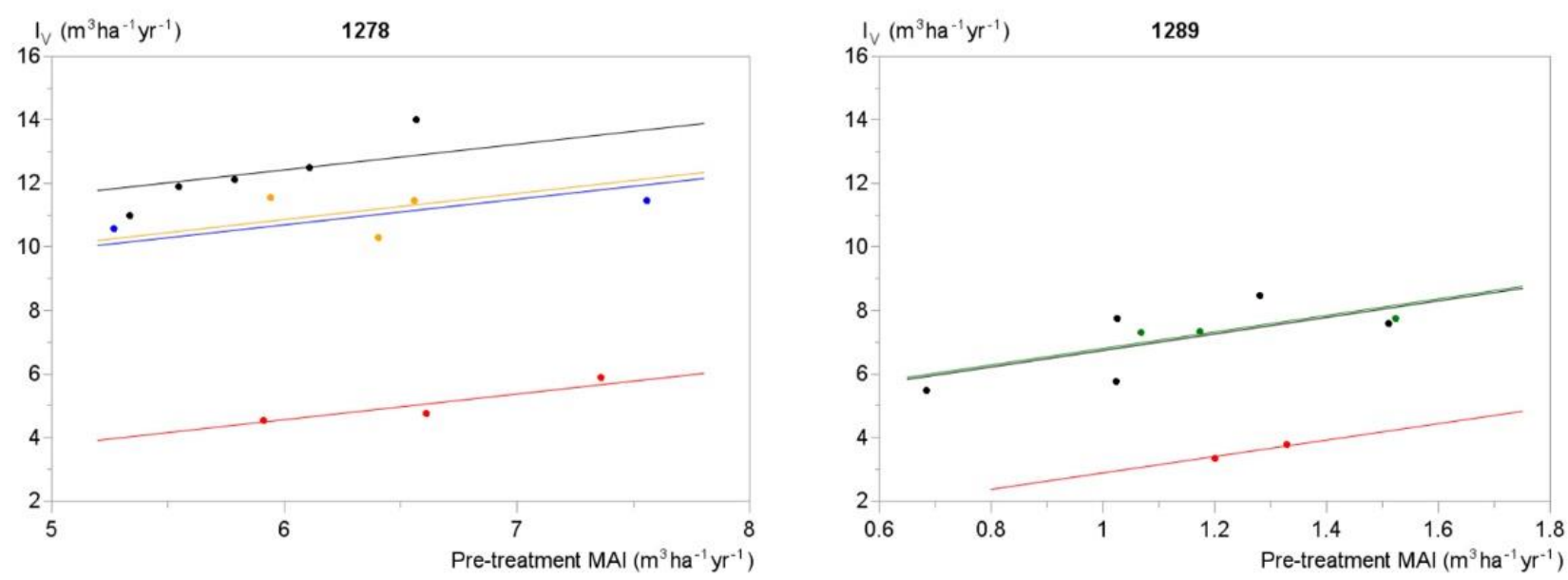

Figure 2. Mean annual stand volume growth $\left(I_{V}, \mathrm{~m}^{3} \mathrm{ha}^{-1} \mathrm{year}^{-1}\right)$ vs. pre-treatment mean annual volume increment $\left(M A I_{\text {pre-trt }}, \mathrm{m}^{3} \mathrm{ha}^{-1}\right.$ year $\left.^{-1}\right)$ depending on treatment. Parameter estimates for the regression lines are given in Table 4. Legend for treatments: UC = black, UC-pruned = green, PT300 = yellow, T1500 = blue, T600 = red.

Table 4. Parameter and LS-means estimates for the final model of stand volume growth depending on treatment and pre-treatment MAI $\left(M A I_{\text {pre-trt }}, \mathrm{m}^{3} \mathrm{ha}^{-1}\right.$ year $\left.^{-1}\right)$. Legend: $n=$ number of observations, $R^{2}=$ coefficient of determination.

\begin{tabular}{|c|c|c|c|}
\hline $\begin{array}{l}\text { Variable/ } \\
\text { Treatment }\end{array}$ & Estimate & $p$-Value & $\begin{array}{r}\text { LS-Means } \\
\left(\mathrm{m}^{3} \mathrm{ha}^{-1} \text { year }^{-1}\right)\end{array}$ \\
\hline \multicolumn{4}{|c|}{ Exp. $1278\left(n=13, R^{2}=0.963^{* * *}\right)$} \\
\hline Intercept & 7.5315 & 0.005 & \\
\hline$M A I_{\text {pre-trt }}$ & 0.8134 & 0.038 & \\
\hline UC & 0.0000 & - & 12.60 \\
\hline РТ300 & -1.5440 & 0.022 & 11.05 \\
\hline $\mathrm{T} 1500$ & -1.7183 & 0.025 & 10.88 \\
\hline T1500 & -7.8607 & $<0.0001$ & 4.74 \\
\hline \multicolumn{4}{|c|}{ Exp. $1289\left(n=11, R^{2}=0.872^{* *}\right)$} \\
\hline Intercept & 4.1405 & 0.017 & \\
\hline$M A I_{\text {pre-trt }}$ & 2.6000 & 0.054 & \\
\hline $\mathrm{UC}$ & 0.0000 & - & 7.21 \\
\hline UC Pruned & 0.0582 & 0.925 & 7.27 \\
\hline T600 & -3.8598 & 0.001 & 3.35 \\
\hline
\end{tabular}

In experiment 1289 (11 plots), stand volume growth during the observation period (age 6-12 years) varied between 3.35 and $8.46 \mathrm{~m}^{3} \mathrm{ha}^{-1}$ year $^{-1}$. One unthinned pruned plot was an outlier and was consequently omitted from the final analysis. The final model included no interaction term.

Pre-treatment MAI was barely significant $(p=0.054)$ in this experiment, but considering the large heterogeneity in site and pre-treatment stand conditions, we decided to keep this variable in the final model. The final model also included thinning treatment (Figure 2). Growth increased with increasing pre-treatment MAI, was largest and essentially identical in unthinned plots, whether without or with some pruned trees, and was substantially smaller in heavily thinned T600 plots (Table 4). LS-means estimates indicated a growth reduction for the T600 treatment by $53.5 \%$ as compared to the unthinned control. 


\subsection{Stand Volume Growth and Slash Management}

Stand volume growth in the T600 treatment of experiment 1278 varied between 4.65 and $6.52 \mathrm{~m}^{3} \mathrm{ha}^{-1}$ year $^{-1}\left(\right.$ mean $=5.30 \mathrm{~m}^{3} \mathrm{ha}^{-1}$ year $\left.^{-1}\right)$ in plot halves with slash extraction and between 4.44 and $5.42 \mathrm{~m}^{3} \mathrm{ha}^{-1}$ year $^{-1}\left(\right.$ mean $=4.89 \mathrm{~m}^{3} \mathrm{ha}^{-1}$ year $\left.^{-1}\right)$ in plot halves with slash retention (age 11-19 years). On average, slash retention reduced growth by $-0.42 \mathrm{~m}^{3} \mathrm{ha}^{-1}$ year $^{-1}$ or approximately $8 \%$ as compared to slash extraction, but the difference between the two treatments was not significant $(p=0.353)$.

\section{3. $D_{300}$ Selection and Treatment Effects}

Due to the selection criteria, $D_{300 i n i t A T}$ was inevitably smaller than $D_{300 i n i t B T}$ in all treatments but the unthinned control. Pre-treatment MAI was not significant in either experiment $\left(P_{1278}=0.108, P_{1289}=0.330\right)$, although scatterplots (not shown) indicated a tendency for increasing selection effect $\left(\Delta_{\text {D300init }}\right)$ with increasing pre-treatment MAI. The relative magnitude of the selection effect (Table 5) was consistent across the two experiments and was largest in the PT300 treatment (15-21\%), smaller in the T600 (9-11\%), and smallest in the T1500 (3.5\%).

Table 5. Quantification of the selection effect depending on thinning practice based on change in $D_{300}$ $\left(\Delta_{D \text { B00init }}\right)$. Percentage change was calculated as $100 \cdot \Delta_{D 300 i n i t} / D_{300 i n i t B T}$. Legend: $s=$ standard deviation.

\begin{tabular}{lcccccc}
\hline & \multicolumn{3}{c}{ Experiment 1278 } & \multicolumn{3}{c}{ Experiment 1289 } \\
\cline { 2 - 7 } Treatment & $\begin{array}{c}\boldsymbol{\Delta}_{\text {D300init }} \\
\mathbf{c m}\end{array}$ & $\begin{array}{c}\boldsymbol{\Delta}_{\text {D300init }} \\
\mathbf{\%}\end{array}$ & $\begin{array}{c}\boldsymbol{s} \\
\mathbf{c m}\end{array}$ & $\begin{array}{c}\boldsymbol{\Delta}_{\text {D300init }} \\
\mathbf{c m}\end{array}$ & $\begin{array}{c}\boldsymbol{\Delta}_{\text {D300init }} \\
\mathbf{\%}\end{array}$ & $\begin{array}{c}\mathrm{s} \\
\mathbf{c m}\end{array}$ \\
\hline T1500 & 0.35 & 3.5 & 0.06 & & & \\
PT300 & 1.53 & 14.6 & 0.19 & 0.95 & 21.0 & 0.10 \\
T600 & 0.93 & 8.8 & 0.33 & 0.54 & 11.0 & 0.08 \\
\hline
\end{tabular}

In experiment $1278, I_{D 300}$ (the average annual increase in $D_{300}$ ) ranged from 0.59 to $0.79 \mathrm{~cm} \cdot$ year $^{-1}$. Two plots were outliers (one T1500 and one UC) and were omitted from the final analysis (these were consequently also omitted from the final analysis of selection effects). Pre-treatment MAI was barely significant $(p=0.131)$, but the trend was evident from the scatterplot (Figure 3). LS-means estimates for $I_{D 300}$ increased by $2 \%$ with point thinning, $8.5 \%$ with T1500 thinning, and 18\% with very heavy T600 thinning, as compared to the unthinned control (Table 6).
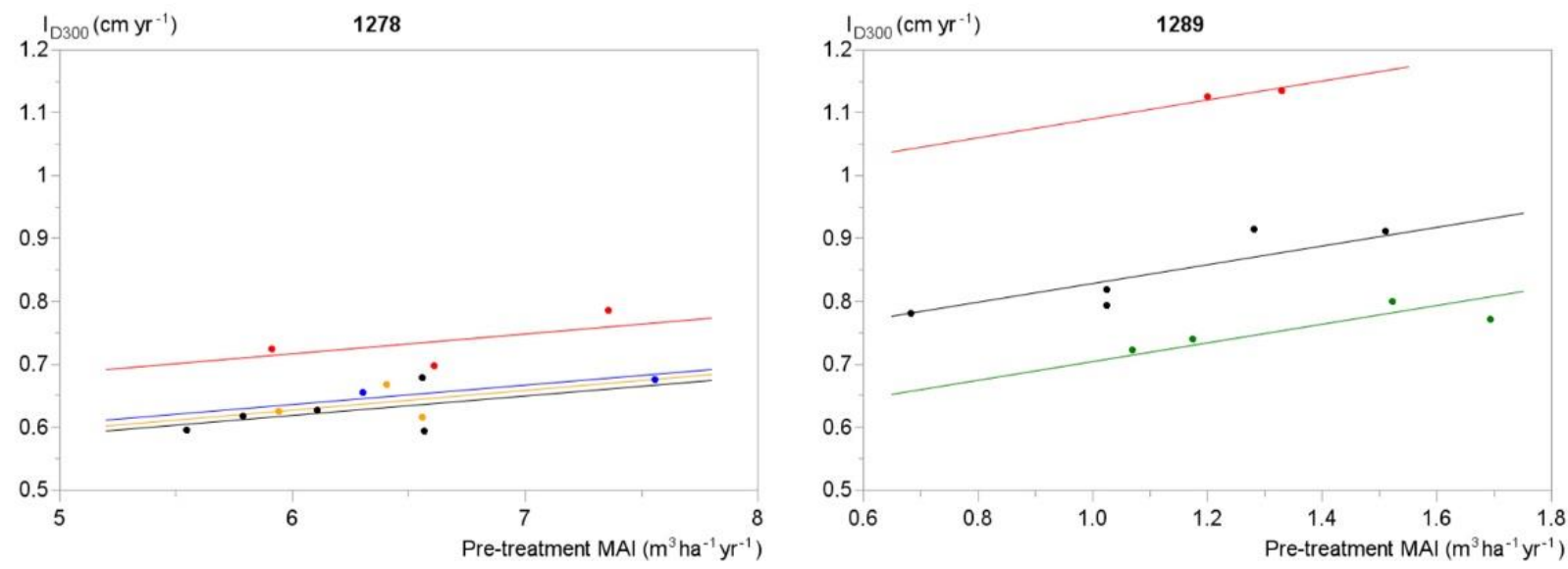

Figure 3. Mean annual change in $D_{300}\left(I_{D 300}, \mathrm{~cm} \cdot\right.$ year $\left.^{-1}\right)$ vs. pre-treatment MAI $\left(M A I_{\text {pre-trt }}, \mathrm{m}^{3} \mathrm{ha}^{-1} \mathrm{year}^{-1}\right)$ depending on treatment. Parameter estimates are given in Table 6. The regression lines for 1278 were not significant $(p=0.131)$ and are shown only for orientation. Legend for treatments: UC = black, UC-pruned = green, PT300 = yellow, T1500 = blue, T600 = red. 
Table 6. Parameter and LS-means estimates for the final model of mean annual change in $D_{300}\left(I_{D 300}\right)$ depending on treatment and pre-treatment MAI. Legend: $n=$ number of observations, $R^{2}=$ coefficient of determination.

\begin{tabular}{|c|c|c|c|}
\hline $\begin{array}{l}\text { Variable/ } \\
\text { Treatment }\end{array}$ & Estimate & $p$-Value & $\begin{array}{r}\text { LS-Means } \\
\left(\mathrm{m}^{3} \mathrm{ha}^{-1} \text { year }^{-1}\right)\end{array}$ \\
\hline \multicolumn{4}{|c|}{ Exp. $1278\left(n=13, R^{2}=0.712^{* *}\right)$} \\
\hline Intercept & 0.6226 & $<0.0001$ & \\
\hline UC & 0.0000 & - & 0.62 \\
\hline РТ300 & 0.0142 & 0.584 & 0.64 \\
\hline T1500 & 0.0427 & 0.170 & 0.67 \\
\hline T600 & 0.1138 & 0.001 & 0.74 \\
\hline \multicolumn{4}{|c|}{ Exp. $1289\left(n=11, R^{2}=0.973^{* * *}\right)$} \\
\hline Intercept & 0.6785 & $<0.0001$ & \\
\hline$M A I_{\text {pre-trt }}$ & 0.1498 & 0.0037 & \\
\hline UC & 0.0000 & & 0.86 \\
\hline UC Pruned & -0.1241 & 0.0006 & 0.74 \\
\hline T600 & 0.2617 & $<0.0001$ & 1.12 \\
\hline
\end{tabular}

In experiment $1289, I_{D 300}$ ranged from 0.72 to $1.13 \mathrm{~cm} \cdot$ year $^{-1}$. According to the final model, $I_{D 300}$ increased with pre-treatment MAI and depended on thinning treatment (Figure 3). Comparing unthinned plots with or without the pruning of 300 trees per ha, LSmeans estimates indicated a reduction in $I_{D 300}$ by $14 \%$ due to pruning (Table 6 ). Comparing unthinned plots and the heavily thinned T600 plots, in both cases without pruning of any trees, T600 thinning resulted in an increase in $I_{D 300}$ by $30 \%$.

\subsection{Crop Tree Growth}

The average annual growth on the dbh of pre-selected potential future crop trees in plots treated with PT300 or T600 in experiment 1278 varied between 0.01 and $1.25 \mathrm{~cm}$ (Figure 4). No interaction terms were significant in any of the three models calibrated.
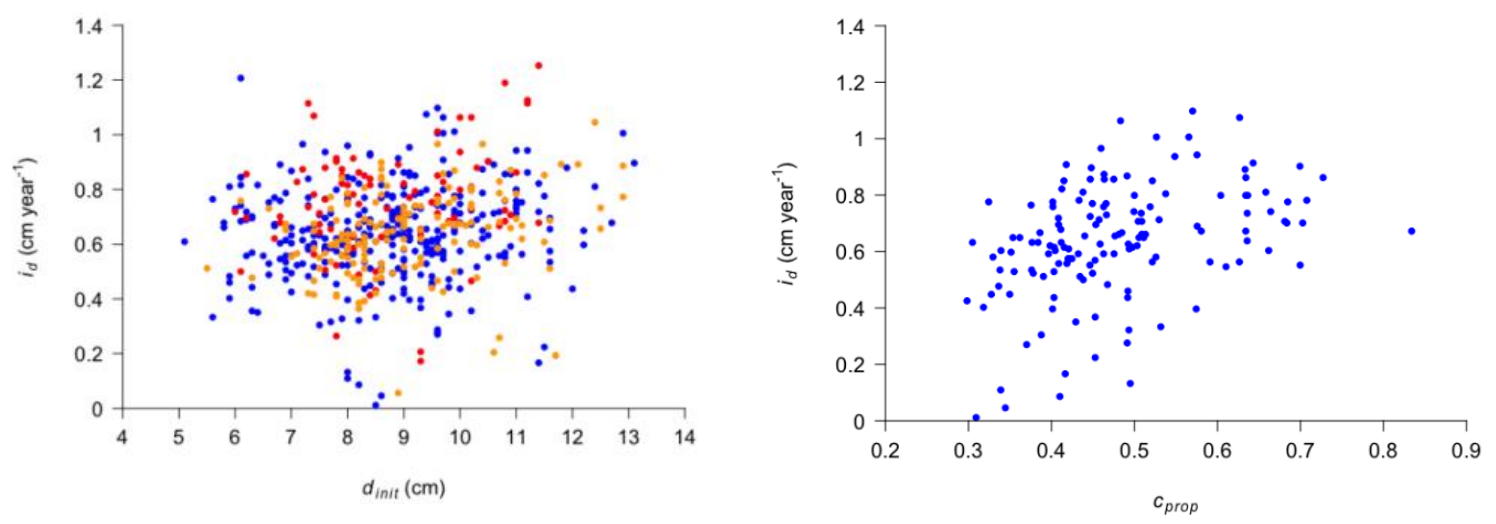

Figure 4. Experiment 1278. Left: individual tree growth $\left(i_{d}\right)$ for crop trees of treatments PT300 and T600 vs. initial stem dbh $\left(d_{\text {init }}\right)$. Right: individual tree growth $\left(i_{d}\right)$ for pruned crop trees of treatment T600 vs. remaining crown proportion $\left(c_{\text {prop }}\right)$. Legend: РT300 unpruned $=$ yellow, T600 unpruned $=$ red, T600 pruned $=$ blue.

According to the final version of Model (5.1) calibrated on all available data, growth on dbh increased with increasing initial dbh (larger stem size), was positively influenced by heavy thinning on the whole plot (T600) as compared to point thinning (PT300) and was negatively influenced by high pruning (Table 7). Using $d_{\text {init }}=8.81 \mathrm{~cm}$ and unpruned trees in PT300 as the baseline, LS-means estimates indicated $21 \%$ larger growth on unpruned trees in T600 and 3\% larger growth on pruned trees in T600 (Table 8). Pruning in T600 led to $14 \%$ less growth on dbh as compared to unpruned T600 trees. For (hypothetical) 
pruned trees in PT300, the model indicates 17\% less growth as compared to unpruned trees in PT300.

Table 7. Parameter estimates for the final model of individual crop tree growth on dbh. Legend: $d_{\text {init }}=$ initial stem $\mathrm{dbh}, c_{l}=$ remaining crown length,$c_{\text {prop }}=$ remaining crown proportion, $n=$ number of observations, $R_{m}^{2}=$ marginal coefficient of determination concerned with variance explained by fixed factors, $R_{c}^{2}=$ conditional coefficient of determination concerned with variance explained by both fixed and random effects, $\sigma_{\alpha}^{2}=$ variance attributed to plot, $\sigma_{\varepsilon}^{2}=$ residual variance.

\begin{tabular}{lrr}
\hline Variable/Treatment & Estimate & $p$-Value \\
\hline Exp. $1278\left(n=568, R_{\mathrm{m}}^{2}=0.083, R_{\mathrm{c}}^{2}=0.116\right)$ & & \\
\cline { 1 - 2 } Fixed & & $<0.001$ \\
Intercept PT300-unpruned & 0.4464 & $<0.001$ \\
$d_{\text {init }}$ & 0.1299 & 0.020 \\
T600 & -0.1097 & $<0.001$ \\
Pruned & & \\
Random & 0.0010 & \\
$\sigma_{a}^{2}$ & 0.0276 & $<0.001$ \\
$\sigma_{\varepsilon}^{2}$ & & $<0.001$ \\
\hline Exp. $1278\left(n=327, R_{\mathrm{m}}^{2}=0.092, R_{\mathrm{c}}^{2}=0.106\right)$ & & \\
\hline Fixed & & \\
Intercept & 0.3567 & \\
$c_{l}$ & 0.1006 & \\
Random & & \\
$\sigma_{a}^{2}$ & 0.0004 & $<0.001$ \\
$\sigma_{\varepsilon}^{2}$ & 0.0266 & \\
\hline Exp. $1278\left(n=143, R_{\mathrm{m}}^{2}=0.147, R_{\mathrm{c}}^{2}=0.156\right)$ & & \\
\hline Fixed & & \\
Intercept & & \\
$c_{\text {prop }}$ Random & & \\
$\sigma_{a}^{2}$ & 0.2867 & \\
$\sigma_{\varepsilon}^{2}$ & 0.7362 & \\
\hline & 0.0003 & \\
\hline & 0.0345 & \\
\hline
\end{tabular}

Table 8. LS-means estimates for the final model of individual crop tree growth on dbh (cf. Table 7).

\begin{tabular}{lrr}
\hline Variable/Treatment & & $\begin{array}{c}\text { LS-Means } \\
\text { (cm year } \text {-1 }^{\text {) }}\end{array}$ \\
\hline Exp. 1278, model 1 & $d_{\text {init }}(\mathrm{cm})$ & \\
\hline PT300 unpruned & 8.81 & 0.631 \\
PT300 pruned & 8.81 & 0.521 \\
T600 unpruned & 8.81 & 0.761 \\
T600 pruned & 8.81 & 0.651 \\
\hline Exp. 1278, model 2 & $c_{l}(\mathrm{~m})$ & \\
\hline Min. & 1.70 & 0.528 \\
Mean & 2.86 & 0.645 \\
Max. & 5.16 & 0.876 \\
\hline Exp. 1278, model 3 & $c_{\text {prop }}$ & \\
\hline Min. & 0.29 & 0.506 \\
Mean & 0.48 & 0.640 \\
Max. & 0.83 & 0.901 \\
\hline
\end{tabular}

Remaining crown length after the pruning of pre-selected potential future crop trees in T600 plots in experiment 1278 varied between 1.70 and $5.16 \mathrm{~m}$. In a subset of trees, the 
remaining crown proportion varied from roughly 30 to $70 \%$ (mean value $=48 \%$ ) and were evenly distributed across this range.

According to the final models for pruned trees only, Model (5.2) for crown length logically indicated increasing growth with increasing crown length, and Model (5.3) for crown proportion indicated increasing growth with increasing proportion of crown remaining after the pruning (Table 7). In these two models, no influence was found of initial dbh, pre-treatment MAI or slash management (retention or extraction). Although calibrated on a smaller number of observations, the crown proportion model had higher $R^{2}$-values than the crown length model. Considering that Model (5.3) was calibrated on a subset of the data used for Model (5.2), LS-means estimates agreed well across the range of data.

\section{Discussion}

\subsection{Stand Volume Growth and Thinning Practice}

In our study of young silver birch, stand volume growth increased with increasing pretreatment stand volume (or pre-treatment mean annual volume increment) and decreased with increasing thinning intensity as compared to the unthinned control. For shade-tolerant tree species, stand volume growth is often quite insensitive to thinning over a broad range of thinning grades (when thinning from below), whereas thinning of light-demanding tree species often leads to a reduction in growth $[32,33]$.

Referring to both experiments, the observed responses of stand volume growth to pre-treatment MAI emphasizes the importance of including an indicator of inherent site productivity in stand level thinning analyses. However, due to the age-related pattern of volume growth, pre-treatment MAI did not allow for an immediate comparison across the experiments. Asynchrony of age across experiments particularly hampers comparisons based on pre-treatment MAI for tree species with rapid growth in youth, such as silver birch, simply because of the relatively large impact of age in calculating MAI.

As an alternative to pre-treatment MAI, pre-treatment stand basal area, stand top height or soil variables could have been used $[29,30]$. In our case, no soil variables were available and site index based on stand top height could not be derived reliably due to the young age of experiment 1289. Moreover, at initiation of the experiment, height in this very young stand might still be influenced by stand establishment practices (the importance of which usually vanishes with increasing age).

The purpose of including a co-variate characterizing the plot or stand at initiation of an experiment obviously is to account for pre-treatment variation among plots and in doing so reducing the residual variation of the final model. Likewise, and considering the within-treatment variation in thinning removals and residual basal area, it could be desirable to specify the treatments numerically rather than as categorical variables, for example, by residual basal area as in classical thinning response analyses [32]. However, this approach is meaningful only if the selection principle is similar across treatments (for example, thinning from below only). Moreover, in our case the specification of treatments by a categorical variable resulted in a higher coefficient of determination.

In 1278 , moderate thinning reduced growth by $14 \%$ and heavy thinning (combined with pruning) by $62 \%$. Adjusting for the pruning on $80 \%$ of the residual trees in heavily thinned plots brings the reduction with heavy thinning down by approximately $0.7 \%$ points ( $14 \%$ less growth on dbh of each pruned tree $\approx$ potentially $2.33 \%$ larger growth on basal area of each unpruned tree (mean $\mathrm{dbh}=8.8 \mathrm{~cm}) \approx 1.86 \%$ larger growth at stand level $\approx$ stand volume growth would have been $38.3 \%$ instead of $37.6 \%$ of the unthinned control). No adjustment was justified for slash extraction on approximately half of each of the heavily thinned plots.

The smaller growth reduction with heavy thinning in 1289 (54\%) could be due to incomplete canopy closure at initiation of the experiment, resulting in less than maximum growth in the unthinned control. Alternatively, the difference between experiments could be due to trees being more responsive at a younger age. This would be in contrast, however, to the response pattern for pedunculate oak (Quercus robur L.), another light-demanding 
species, for which the growth reduction due to thinning (relative to the unthinned control) decreases with increasing age [34].

Interestingly, point thinning resulted in a growth reduction almost identical to that of moderate thinning throughout the whole plot (exp. 1278). With point thinning the only trees removed in thinning were immediate competitors of the potential future crop trees, and no thinning was carried out in the space between these. This means that the thinning response of pre-selected potential future crop trees did not completely compensate for the reduction in stand growth due to the thinning removal.

On a pro rata basis, the reduction/removal-ratio for moderate thinning was 0.46 and for point thinning 0.60 . This supports the growth reduction as being located mainly in pre-selected potential future trees. In 1278, the reduction/removal-ratio for heavy thinning was 0.85 (adjusted to 600 trees per ha and no pruning), and in 1289 it was 0.80 .

Clearly, there was a disproportionately large reduction in stand volume growth with heavy thinning. Moreover, there was less reduction with thinning scattered throughout the stand as compared to point thinning. Both of these results indicate that canopy closure, or the regain of canopy closure, is essential in order for young birch stands to fully utilize the growth potential. However, the long-term effect of one or few heavy thinning interventions (such as T600) as compared to repeated moderate thinning (such as T1500) still has to be evaluated. The quantification of these relationships throughout the rotation will depend on the long-term development of the experiments.

Only a few other studies quantify the influence of thinning practice on stand growth in even-aged silver birch. In Finland, preliminary results from a series of 14 experiments somewhat comparable to experiment 1278 indicated a similar response to thinning intensity. For example, in the experiment at Padasjoki (160 km north of Helsinki), initiated at a slightly more advanced stage of stand development, two thinning operations, first to $50 \%$, then to $35 \%$ of the basal area of the unthinned control, reduced stem volume growth by approximately $30 \%$, with lighter thinning regimes leading to less reduction [5].

In Canada, results from an experiment in 9-13 year-old naturally regenerated paper birch (Betula papyrifera Marsh.) with three from-below thinning treatments and an unthinned control, all replicated three times on each of the four different sites, indicated a response pattern for 5-year post-treatment growth similar to that of experiment 1278 [35]. The experiment included residual stem densities of 3000, 1000 and 400 trees per ha. Post-treatment plots had a sparse admixture of other tree species. Based on mean values reported in the publication, we calculated the thinning removals at $54 \%, 69 \%$ and $83 \%$, respectively, and the residual basal areas at $42 \%, 26 \%$ and $14 \%$, respectively. The resulting growth reductions (based on stem volume inside bark) were $34 \%, 59 \%$ and $74 \%$, respectively, as compared to the unthinned control, and the corresponding reduction/removal-ratios were $0.62,0.85$ and 0.89 .

Our results for silver birch are clearly consistent with those reported for paper birch. Consequently, results from the experiments in Sweden and from the experiment in Canada may be combined and summarized in a simple model for birch of growth reduction at stand level as a linear function of thinning removal, with both variables expressed as a percentage of the unthinned control (Figure 5). In the absence of better information, this model may serve to provide an indication of the expected growth reduction for from-below thinning in young birch stands and could be used for developing thinning guidelines.

\subsection{Stand Volume Growth and Slash Management}

The slash extraction in heavily thinned plots of experiment 1278 comprised $71-75 \%$ of the total above-ground wood volume on the area and thus represented a rather substantial removal. Slash extraction had no statistically significant impact on volume growth at stand level for the entire observation period (eight years after the first and only thinning intervention). No re-measurements were made during the observation period, so the temporal development in growth could not be specified. The possible influence of slash management also remained undetected in the growth of individual, pruned crop trees when using crown length or remaining crown proportion as main predictor. 


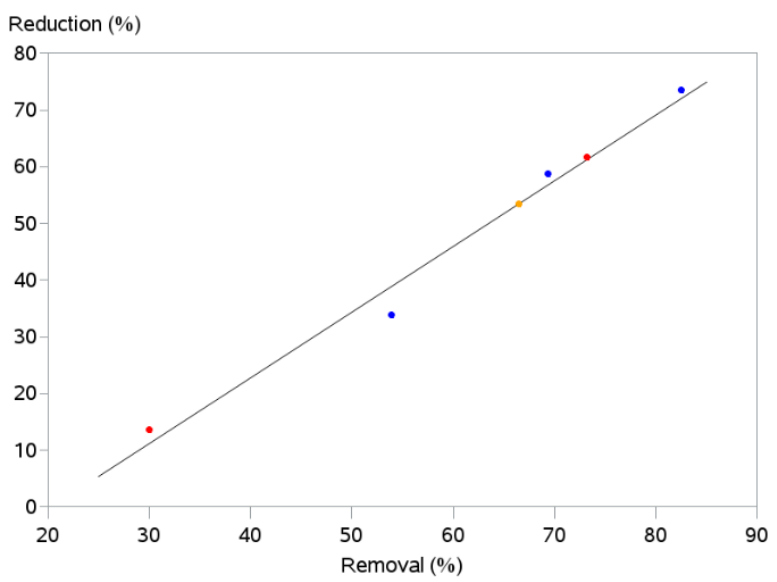

Figure 5. Results from experiments 1278 (red dots) and 1289 (yellow dot) in Sweden and an experiment (blue dots) in Canada [35] summarized in a simple model for the reduction in stand volume growth $(\operatorname{Red} I v \%)$ as a linear function of thinning removal $\left(\operatorname{Rem}{ }_{V} \%\right)$, both expressed as a percentage of the unthinned control. Excluding point thinning, for which the selection criteria differ substantially, the following model was calibrated (black line): $\operatorname{Red}_{I v \%}=-23.67+1.16 \cdot \operatorname{Rem}_{V \%}\left(R^{2}=0.980^{* * *}, n=6\right.$, calibration range: $30-83 \%)$.

Whole-tree harvesting without stump and root extraction is the most common type of slash removal and has been studied extensively mainly in conifer-dominated forest types. The impact on tree growth tends to be site-specific, in the short-term negative, and in the long-term less clear (e.g., [36-38]). One study comprising two-storied stands of silver birch (overstorey) and Norway spruce (understorey, 20-30 years old) found no short-term influence of whole-tree harvesting of birch on the growth of either species in the residual stand [39]. However, in all such studies, site- or management-specific confounding factors may mask any direct effect of slash management (e.g., [40-42]).

Logically, harvesting combined with slash extraction removes nutrients that would otherwise remain on the area to become available for residual trees and other vegetation. Harvesting of stump and root systems obviously further depletes the nutrient pool [43]. Other contributing factors to site modification include soil compaction by machinery and derived effects from change in microclimate near the soil surface brought about by the presence or absence of slash. In turn, any or all of these site modifications may influence long-term site productivity.

As judged by the subsequent development of ground flora in different T600 plot halves of experiment 1278, site modification became apparent soon after the thinning intervention. Similar indications of site modification are known from a thinning experiment in young pedunculate oak in Denmark [44]. The degree of cover and the diversity of ground flora were inventoried in great detail when the experiments were initiated, but have not been re-inventoried. Any quantitative correlation with site or stand productivity remains to be investigated.

Slash (harvest residues) is an abundant by-product in managed forests, with significant potential as feedstock for renewable energy systems or advanced biomaterials. Slash management is nutrient management, but it also involves biodiversity, soil properties and other issues not included in our study. Due to the potentially conflicting interests of commercial slash extraction, forest productivity and environmental concerns, slash management may be critical for long-term forest sustainability and warrants further consideration.

From an operational perspective, slash retention may be a problem in heavily thinned stands simply because the slash may hamper access to the area (for example, for subsequent pruning). However, during thinning operations in young stands, slash can easily, and at little cost, be arranged in lines, for example, along rows or transportation tracks, and this is recommended. 


\section{3. $D_{300}$ Selection and Treatment Effects}

The relative magnitude of the selection effect was consistent across the two experiments as measured by the instantaneous numeric change in $D_{300}$ due to thinning. The selection effect was largest with point thinning (PT300, 15-21\%), smaller with heavy thinning (T600, 9-11\%), and smallest with moderate thinning (T1500, 3.5\%).

The selection was supervised by the senior author in both experiments and was implemented by two different co-authors (one for each experiment). The consistency indicates adherence to the general guidelines. For PT300 and T600, these can be summarized as positive selection for regular spatial distribution, superior growth potential, high stem quality, absence of visible 'defects', and good health. In contrast, selection in T1500 was negative and against undesired trees in the stand. This resulted in less change in $D_{300}$. Although the selection criteria for potential future crop trees were, in principle, identical for PT300 and T600, the prescribed treatment of each plot was known in advance and clearly influenced the selection.

During selection in PT300, it was considered that nearby neighbor trees on the periphery of the gap created around each selected crop tree will remain in the stand for a while and that the gap will be gradually enlarged in subsequent thinning interventions. Moreover, it was considered that pruning was not an option for improving stem quality (pruning of trees in PT300 plots of experiment 1289 was decided at a later stage and did not influence the selection of crop trees).

During selection in T600, it was considered that the (best) trees were to be pruned, so branch size mattered less. Consequently, different types of trees were selected and there was a different attitude to, for example, wolf trees (dominant trees with short stem, thick branches and widely spreading crown). Finally, the selection of 600 vs. 300 trees worked in a similar direction.

In experiment 1278 , the average annual change in $D_{300}, I_{D 300}$, increased with increasing thinning intensity. This could indicate that potential future crop trees in PT300 plots would have benefitted from thinning sooner than after eight years.

In experiment $1289, I_{D 300}$ was substantially larger than in 1278 , reflecting the rapid growth in the youth of silver birch and its vigorous, but with age declining, responsiveness to increasing space. Moreover, $I_{D 300}$ in 1289 clearly demonstrated the negative impact of pruning and the positive impact of heavy thinning on the growth of pre-selected crop trees as compared to socially dominant trees in unpruned or unthinned stands, respectively.

\subsection{Crop Tree Growth}

The analyses of crop tree growth in experiment 1278 revealed $21 \%$ larger growth on the dbh of unpruned trees in heavily thinned plots as compared to unpruned trees in point thinning plots, while pruned trees in heavily thinned plots had 3\% larger growth than unpruned trees in point thinning plots and $14 \%$ less than unpruned trees in heavily thinned plots. In other words, most of the growth stimulation due to thinning was lost in pruning.

This result is in line with the analysis of the $D_{300}$ treatment effect and, as for the pruning in heavily thinned plots, with results from a similar experiment in young European beech (Fagus sylvatica L.). The beech experiment comprised unthinned control plots, strip thinning removing $50 \%$ of the stem number, and heavy thinning (with or without pruning) leaving only 200 trees per ha [45]. Potential future crop trees had been selected in all treatments and according to criteria identical to those used in our birch experiments.

Although not explicitly part of the selection criteria, potential future crop trees were selected partly based on social dominance. Larger growth on dbh of socially dominant trees following thinning has been observed in a number of other studies, including some for silver birch in Finland [4,5], paper birch in North America [35,46] and beech in Europe [47-49].

Diameter growth generally increases with increasing growing space, but it was somewhat surprising that heavy thinning as applied in the T600 treatment resulted in increased $\mathrm{dbh}$ growth as the dramatic change in stand-interior forest conditions resulting from this treatment might be expected to reduce stand level as well as individual tree growth. The 
increase in dbh growth was reduced when heavy thinning was combined with pruning, reflecting the immediate reduction in foliage volume. Due to the lack of re-measurements on an annual basis, the temporal pattern of individual tree growth, i.e., the immediate growth reduction due to foliage loss followed by a gradual recovery, could not be quantified.

The two models that include measurements of remaining crown size quantify the reduction in growth for the duration of the whole observation period depending on remaining crown length or on the proportion of crown remaining after pruning. Due to the overwhelmingly large number of unpruned trees and their variability in growth, neither of these models could be calibrated in a meaningful way by including unpruned trees (crown proportion $=1.0$ ) in calibration data. Anyhow, the models were calibrated for a large range of pruning severity and clearly indicate larger growth on stem diameter with larger crown and larger growth with larger remaining crown proportion.

In experiment 1278 , roughly $30-70 \%$ of the crown length was removed in the pruning. Extrapolating from this range to $100 \%$, the model for remaining crown proportion indicates a growth reduction for $\mathrm{dbh}$ at approximately $50 \%$ when removing two-thirds of the crown and at approximately $25 \%$ when removing one-third. This is qualitatively and quantitatively consistent with studies of birch species in Asia [50,51] and North America [52-54]. Moreover, the sensitivity of birch to reductions in foliage at tree level is consistent with its sensitivity or limited capacity at stand level to recover from thinning.

\subsection{Windthrow}

As an unintended side-effect of heavy thinning, all T600 plots in experiment 1278 were damaged during a windstorm in the autumn of 2013, three growing seasons after thinning. Damage occurred mainly in streaks along the main direction of the wind and the proportion of damaged trees was evenly distributed among plot halves, except one plot half with a three times larger blowdown. Being located near the northern (upwind) edge of the forest, this plot was more exposed. No other treatments suffered notable damage.

Most of the damaged trees were uprooted, possibly influenced by the combination of organic soil, poor drainage (shallow root systems) and widespread root rot due to Heterobasidion annosum (Fr.) Bref. (identified in stem disc samples), Armillaria gallica Marxm. and Romagn. (identified on site by rhizomes) or other, unidentified fungi. However, the occurrence of root rot was investigated prior to the windstorm and was not restricted to T600 plots. Moreover, no pattern relating to site conditions or slash management was apparent in the spatial distribution of the wind damage.

A likely explanation for the observed windthrow pattern is increased canopy roughness due to canopy gaps created by thinning as this makes recently thinned stands more vulnerable (cf. [55]). Following heavy thinning, wind can penetrate deeper into the canopy with a subsequent increase in the wind load imposed on the remaining trees, while dense stands dissipate incoming wind. A tree is uprooted if the total turning moment exceeds the support provided by the root-soil plate anchorage, and if the stem does not break prior to uprooting. The canopy closure and the root expansion following thinning may gradually improve stand stability but, apparently, this process had not progressed sufficiently in the T600 plots of experiment 1278 .

For birch growing in average forest conditions, mechanistic simulation studies indicate that the critical wind speed for uprooting $12 \mathrm{~m}$ tall trees is 1.5-2 times larger for trees without than for trees with leaves and increases by $50 \%$, to approximately $32 \mathrm{~m} \cdot \mathrm{s}^{-1}$, for an increase in dbh from 10 to $15 \mathrm{~cm}$ [56]. Based on linear interpolation, stand top heights (dominant trees) in our T600 plots were 10.4-11.4 m at the time of the 2013-windstorm. However, the combination of age, height and stand density was probably beyond the calibration range of the model.

The more widespread damage at the long-established upwind forest edge or, more accurately, immediately behind the edge, is consistent with general experience in silviculture [57], wind simulation studies [58] and research on birch [59]. Consistent with the 
simulation studies specifically for birch [56], unthinned plots and 'normally' thinned plots (stand top height $\approx 10.1-11.7 \mathrm{~m}$ ) in experiment 1278 remained undamaged.

Broadleaved forest usually remains unaffected by windstorms during the dormant season [60-62]. Nevertheless, our observations indicate that heavily thinned stands of birch are vulnerable to windthrow for some years following thinning intervention. We found no other reports of this in literature. However, plots of young pedunculate oak thinned to a residual stem density of 300 or 100 trees per ha, replicated in five experimental blocks on three different glacial till sites in Denmark [44,63], all suffered damage in windstorms shortly after the first thinning intervention. In the oak experiments, windthrow occurred mainly on high terrain or on moist parts of the area, and most damaged trees were blown into a leaning stem position rather than being uprooted or having the stem broken (based on unpublished data collected by the senior author). This is consistent with differences in soil type (organic soil vs. glacial till) and with the general notion of better root anchorage for oak than for birch.

Observations of windthrow are almost always situational. This also holds for our study and we consequently caution the general validity of our interpretations and of suggested hypotheses. Nevertheless, any observations from accidental case studies such as this may accumulate to form or corroborate scientific hypotheses, whether testable or untestable.

\section{Conclusions}

Despite the importance of silver birch in boreal and, to some extent, temperate forests in Europe and Asia, the effects of early thinning and pruning on tree and stand growth are poorly quantified in research literature, and the effect of slash management remains un-investigated or, at least, un-reported. Our study in even-aged stands of silver birch aged 6-19 years demonstrates a general reduction in stand level growth with increasing thinning intensity as compared to the strictly unthinned control. Even less severe removals such as with point thinning reduced growth at stand level. For heavy thinning with large quantities of slash, we found no significant reduction in stand level growth after slash extraction. The growth of pre-selected potential future crop trees increased with increasing thinning intensity. In heavily thinned plots, pruning reduced growth increasingly with increasing pruning severity. Throughout, the temporal trend in growth responses during the observation periods was not included in the analyses.

Author Contributions: Conceptualization and research methodology: J.P.S.; Field experimentsdesign, installation, maintenance and supervision of field work: J.P.S., U.J.; Field work: E.H., R.M.T., C.O.; Formal analysis: J.P.S., G.A.; Data curation: J.P.S., U.J., E.H., R.M.T., C.O., G.A.; Writingoriginal draft: J.P.S.; Writing—review and editing: J.P.S., U.J., E.H., R.M.T., C.O., G.A.; Visualization: J.P.S., G.A.; Funding Acquisition: J.P.S., U.J.; Project supervision and administration: J.P.S. All authors agreed to the order of authors. All authors have read and agreed to the published version of the manuscript.

Funding: This work was supported by the Swedish forest-owner association Södra and the Swedish national research program Future Forests. C. Ols was funded by the French National Research Agency (ANR-11-LABX-0002-01 and ANR-15-IDEX-04-LUE) during her review and editing of the paper.

Acknowledgments: We gratefully acknowledge support from the landowners and managers of the field experiments. Thomas Nord-Larsen, University of Copenhagen, most kindly commented the draft manuscript.

Conflicts of Interest: The authors declare no conflict of interest.

\section{References}

1. Nilsson, P.; Roberge, J.; Fridman, C.; Wulff, S. Forest Statistics 2019; Swedish University of Agricultural Sciences: Umeå, Sweden, 2019; p. 138. Available online: www.slu.se/nfi (accessed on 20 March 2020 and amended with unpublished forest inventory data 2014-2018 for silver and downy birch (personal communication with J. Fridman, 20 March 2020)).

2. Fries, J. Yield of Betula verrucosa Ehrh. in middle Sweden and southern north Sweden. Studia For. Suec. 1964, 14, 1-303. 
3. Juodvalkis, A.; Kairiukstis, L.; Vasiliauskas, R. Effects of thinning on growth of six tree species in north-temperate forests of Lithuania. Eur. J. For. Res. 2005, 124, 187-192. [CrossRef]

4. Niemistö, P. Ensiharvennuksen ajankohdan ja voimakkuuden vaikutus istutetun rauduskoivikon kasvuun ja tuotokseen. Metsätieteen aikakauskirja. Folia For. 1997, 4, 439-454.

5. Niemistö, P. Silver birch thinning experiment 845 in Padasjoki and summary from 13 similar experiments in southern and central Finland. Notes for SNS Forest Production ('Growth E Yield') Group on Field Tour in Finland 2019. Luke, 2019. p. 2. Available online: https:/ / www.luke.fi/projektit/gyn2019/ (accessed on 13 February 2021).

6. Rytter, L.; Werner, M. Influence of early thinning in broadleaved stands on development of remaining stems. Scand. J. For. Res. 2007, 22, 198-210. [CrossRef]

7. Zâlîtis, T.; Zâlîtis, P. Growth of young stands of silver birch (Betula pendula Roth) depending on pre-commercial thinning intensity. Baltic For. 2007, 13, 61-67.

8. Niemistö, P. Effect of growing density on biomass and stem volume growth of downy birch stands on peatland in western and northern Finland. Silva Fenn. 2013, 47, 1002. [CrossRef]

9. Rytter, L.; Karlsson, A.; Karlsson, M.; Stener, L.-G. Skötsel av björk, al och asp. Skogsskötselserien 2008, 9, 1-122.

10. Niemistö, P.; Kilpeläinen, H.; Heräjärvi, H. Effect of pruning season and tool on knot occlusion and stem discolouration in Betula pendula—situation five years after pruning. Silva Fenn. 2019, 53, 10052. [CrossRef]

11. Stener, L.-G.; Rytter, L.; Jansson, G. Effects of pruning on wood properties of planted silver birch in southern Sweden. Silva Fenn. 2017, 51, 1713. [CrossRef]

12. Skovsgaard, J.P.; Ols, C.; McCarthy, R. High-pruning of silver birch (Betula pendula Roth): Work efficiency as a function of pruning method, pole saw type, slash removal, operator, pruning height and branch characteristics. Int. J. For. Eng. 2018, 29, 117-127. [CrossRef]

13. Žumer, M. Astungsversuche an Föhre, Fichte, Birke, Aspe, Esche und Eiche. Det Norske Skogforsøksvesen 1966, $20,399-581$.

14. Skovsgaard, J.P.; Graversgaard, H.C. Skovdyrkning med små træarter: Tidlig udpegning af hovedtræer kombineret med opkvistning. Skoven 2019, 51, 248-251.

15. Dong, P.H.; Tabel, U.; Ehrhart und, H.-P.; Eder, W. Birken-Anbau-Versuch im Forstamt Johanniskreuz. Mitteilungen aus der Forschungsanstalt für Waldökologie und Forstwirtschaft Rheinland-Pfalz 2009, 67, 56-74.

16. Hein, S.; Winterhalter, D.; Wilhelm, G.J.; Kohnle, U. Wertholzproduktion mit der Sandbirke (Betula pendula Roth): Waldbauliche Möglichkeiten und Grenzen. Allg. For. Jagdztg. 2009, 180, 206-219.

17. Hynynen, J.; Niemistö, P.; Viherä-Aarnio, A.; Brunner, A.; Hein, S.; Velling, P. Silviculture of birch (Betula pendula Roth and Betula pubescens Ehrh.) in northern Europe. Forestry 2010, 83, 103-119. [CrossRef]

18. Lemaire, J. Le bouleau: Conduite et sylviculture. For. Entrep. 2000, 136, 25-29.

19. Lemaire, J. Culture d'arbre et détourage du bouleau verruqueux. For. Entrep. 2004, 159, 14-18.

20. Wilhelm, G.J.; Rieger, H. Naturnahe Waldwirtschaft mit der QD-Strategie; Ulmer: Stuttgart, Germany, 2013 ; p. 207.

21. Skovsgaard, J.P.; Holmström, E.; Mc Carthy, R.; Ols, C. Thinning and pruning of silver birch in Sweden. Experiment no. 1278 at Duveke. Southern Swedish Forest Research Centre, Field Experiments in Silviculture, Establishment Report 2014, 2, 1-66.

22. Skovsgaard, J.P.; Ols, C. Thinning and pruning of silver birch in Sweden. Experiment no. 1289 at Vallerstad. Southern Swedish Forest Research Centre, Field Experiments in Silviculture, Establishment Report 2014, 3, 1-60.

23. Stener, L.-G.; Karlsson, B. Förädlad björk och hybridasp, snabbt växande alternativ för södra Sverige. Resultat från Skogforsk $2007,7,1-4$.

24. Söderström, V. Ekonomisk Skogsproduktion; LTs förlag: Vekerum, Sweden, 1971; p. 391.

25. Näslund, M. Skogsförsöksanstaltens gallringsförsök i tallskog. In Meddelanden från Statens Skogsförsöksanstalt; Statens skogsförsöksanstalt: Stockholm, Sweden, 1936; Volume 29, pp. 1-169.

26. Petterson, H. Barrskogens volymproduktion. In Meddelanden från Statens Skogsforskningsinstitut; Statens skogsförsöksanstalt: Stockholm, Sweden, 1955; Volume 45, pp. 1-391.

27. Brandel, G. Volymfunktioner för enskilda träd. Tall, gran och björk. In Sveriges Lantbruksuniversitet, Institutionen för Skogsproduktion, Rapport; Institutionen för Skogsproduktion, Sveriges Lantbruksuniversitet: Garpenberg, Sweden, 1990; Volume 26, pp. 1-183.

28. Andersson, S.-O. Funktioner och tabeller för kubering av småträd. In Meddelanden från Statens Skogsforskningsinstitut; Statens skogsförsöksanstalt: Stockholm, Sweden, 1954; Volume 44, pp. 1-29.

29. Skovsgaard, J.P. The European stem number experiment in Norway spruce (Picea abies (L.) Karst.), 3rd Report; Berichte Freiburger Forstliche Forschung: Baden-Württemberg, Germany, 2006; Volume 66, pp. 13-35.

30. Skovsgaard, J.P. Analysing effects of thinning on stand volume growth in relation to site conditions: A case study for even-aged Sitka spruce (Picea sitchensis (Bong.) Carr.). Forestry 2009, 82, 87-104. [CrossRef]

31. Nakagawa, S.; Schielzeth, H. A general and simple method for obtaining $R^{2}$ from generalized linear mixed-effects models. Methods Ecol. Evol. 2013, 4, 133-142. [CrossRef]

32. Skovsgaard, J.P.; Vanclay, J.K. Forest site productivity: A review of the evolution of dendrometric concepts for even-aged stands. Forestry 2008, 81, 13-31. [CrossRef]

33. Skovsgaard, J.P.; Vanclay, J.K. Forest site productivity: A review of spatial and temporal variability in natural site conditions. Forestry 2013, 86, 305-315. [CrossRef] 
34. Attocchi, G.; Skovsgaard, J.P. Effects of thinning on the stand volume growth of pedunculate oak (Quercus robur L.); Unpublished manuscript, still in progress, 2014.

35. Simard, S.W.; Blenner-Hassett, T.; Cameron, I.R. Pre-commercial thinning effects on growth, yield and mortality in even-aged paper birch stands in British Columbia. For. Ecol. Manag. 2004, 190, 163-178. [CrossRef]

36. Helmisaari, H.-S.; Holt Hanssen, K.; Jacobson, S.; Kukkola, M.; Luiro, J.; Saarsalmi, A.; Tamminen, P.P.; Tveite, B. Logging residue removal after thinning in Nordic boreal forests: Long-term impact on tree growth. For. Ecol. Manag. 2011, 261, $1919-1927$. [CrossRef]

37. Jacobson, S.; Kukkola, M.; Mälkönen, E.; Tveite, B. Impact of whole-tree harvesting and compensatory fertilization on growth of coniferous thinning stands. For. Ecol. Manag. 2000, 129, 41-51. [CrossRef]

38. Nord-Larsen, T. Stand and site productivity response following whole-tree harvesting in early thinnings of Norway spruce (Picea abies (L.) Karst.). Biomass Bioenergy 2002, 23, 1-12. [CrossRef]

39. Mård, H. Short-term growth effects of whole-tree harvest in early thinnings of birch (Betula spp.) and Picea abies. Scand. J. For. Res. 1998, 13, 317-323. [CrossRef]

40. Powers, R.F.; Scott, D.A.; Sanchez, F.G.; Voldseth, R.A.; Page-Dumroese, D.; Elioff, J.D.; Stone, D.M. The North American long-term soil productivity experiment: Findings from the first decade of research. For. Ecol. Manag. 2005, 220, 31-50. [CrossRef]

41. Premer, M.I.; Froese, R.E.; Vance, E.D. Whole-tree harvest and residue recovery in commercial aspen: Implications to forest growth and soil productivity across a rotation. For. Ecol. Manag. 2019, 447, 130-138. [CrossRef]

42. Slesak, R.A.; Palik, B.J.; D'Amato, A.W.; Kurth, V.J. Changes in soil physical and chemical properties following organic matter removal and compaction: 20-year response of the aspen Lake-States Long Term Soil Productivity installations. For. Ecol. Manag. 2017, 392, 68-77. [CrossRef]

43. Hellsten, S.; Helmisaari, H.-S.; Melin, Y.; Skovsgaard, J.P.; Kaakinen, S.; Kukkola, M.; Saarsalmi, A.; Petersson, H.; Akselsson, C. Nutrient concentrations in stumps and coarse roots of Norway spruce, Scots pine and silver birch in Sweden, Finland and Denmark. For. Ecol. Manag. 2013, 290, 40-48. [CrossRef]

44. Rune, F.; Skovsgaard, J.P. Afforestation with oak: Effects of pre-commercial thinning on the development of ground flora. Tema-Nord 2007, 508, 203-209.

45. Reventlow, D.O.; Nord-Larsen, T.; Skovsgaard, J.P. Pre-commercial thinning in naturally regenerated stands of European beech (Fagus sylvatica L.): Effects of thinning pattern, stand density and pruning on tree growth and stem quality. Forestry 2019, 92, 120-132.

46. Graham, J.S. Thinning increases diameter growth of paper birch in the Susitna Valley, Alaska: 20 year results. North. J. Appl. For. 1998, 15, 113-115. [CrossRef]

47. Bončina, A.; Kadunc, A.; Robic, D. Effects of selective thinning on growth and development of beech (Fagus sylvatica L.) forest stands in south-eastern Slovenia. Ann. For. Sci. 2007, 64, 47-57. [CrossRef]

48. Diaconu, D.; Kahle, H.-P.; Spiecker, H. Tree- and stand-level thinning effects on growth of European beech (Fagus sylvatica L.) on a northeast-and a southwest-facing slope in southwest Germany. Forests 2015, 6, 3256-3277. [CrossRef]

49. Klädtke, J. Wachstum großkroniger Buchen und waldbauliche Konsequenzen. Forstarchiv 2002, 73, $211-217$.

50. Sun, Z.; Wang, Q.; Liang, S. Effects of thinning and pruning on the growth of white birch in natural forests. J. North. For. Univ. 2004, 32, 18.

51. Wang, C.; Wu, L.; Zhao, Z.; Lin, T.; Guo, J.; Sha, E.; Zeng, J. Effects of pruning height on growth performance of young plantations of Betula alnoides. J. Cent. S. Univ. For. Technol. 2012, 2012, 09. [CrossRef]

52. Godman, R.M.; Marquis, D.A. Thinning and pruning in young birch stands. In Birch Symposium Proceedings; Northeastern Forest Experiment Station, USDA Forest Service: Washington, DC, USA, 1969; pp. 119-127.

53. Skilling, D.D. Response of yellow birch to artificial pruning. J. For. 1959, 57, 429-432.

54. Solomon, D.S.; Blum, B.M. Effects of Pruning Height on the Diameter Growth of Yellow Birch. Research Note NE-233; USDA Forest Service, Northeastern Forest Experiment Station; Washington, DC, USA, 1977; pp. 1-3.

55. Dupont, S.; Pivato, D.; Brunet, Y. Wind damage propagation in forests. Agric. For. Meteorol. 2015, 214-215, 243-251. [CrossRef]

56. Peltola, H.; Kellomäki, S.; Väisänen, H.; Ikonen, V.-P. A mechanistic model for assessing the risk of wind and snow damage to single trees and stands of Scots pine, Norway spruce, and birch. Can. J. For. Res. 1999, 29, 647-661. [CrossRef]

57. Quine, C.; Coutts, M.; Gardiner, B.; Pyatt, G. Forests and wind: Management to minimize damage. For. Comm. Bull. 1995, 114, 1-24.

58. Dupont, S.; Brunet, Y. Impact of forest edge shape on tree stability: A large-eddy simulation study. Forestry 2008, 81, 299-315. [CrossRef]

59. Zubizarreta-Gerendiain, A.; Pellikka, P.; Garcia-Gonzalo, J.; Ikonen, V.-P.; Peltola, H. Factors affecting wind and snow damage of individual trees in a small management unit in Finland: Assessment based on inventoried damage and mechanistic modelling. Silva Fenn. 2012, 46, 181-196. [CrossRef]

60. Jørgensen, B.B. Erfaringer om stormfasthed fra FSL's langsigtede forsøg. Dansk Skovbr. Tidsskr. 2001, 86, 145-208.

61. Jørgensen, B.B.; Nielsen, C.N. Træarters stormfasthed. Skoven 2001, 33, 14-18.

62. Møller, C.M. Vore skovtræarter og deres dyrkning; Dansk Skovforening: Copenhagen, Denmark, 1965; p. 552.

63. Jensen, F.S.; Skovsgaard, J.P. Precommercial thinning of pedunculate oak: Recreational preferences of the population of Denmark for different thinning practices in young stands. Scand. J. For. Res. 2009, 24, 28-36. [CrossRef] 